Proc. Estonian Acad. Sci. Biol. Ecol., 2003, 52, 2, 125-133

\title{
Comparison of net primary production rates of Pilayella littoralis (L.) Kjellm. and other dominating macroalgal species in Kõiguste Bay, northeastern Baltic Sea
}

\author{
Tiina Paalme $e^{\mathrm{a}, \mathrm{b} *}$ and Henn Kukk ${ }^{\mathrm{a}, \mathrm{b}}$ \\ a Estonian Marine Institute, University of Tartu, Marja 4D, 10617 Tallinn, Estonia \\ ${ }^{\mathrm{b}}$ Faculty of Mathematics and Natural Sciences, Tallinn Educational University, Narva mnt. 25, \\ 10120 Tallinn, Estonia
}

Received 3 May 2002, in revised form 31 October 2002

\begin{abstract}
In situ net primary production measurements by means of the oxygen method were carried out with the ephemeral brown alga Pilayella littoralis, which dominates in the benthic vegetation in Kõiguste Bay, NE Baltic Sea. P. littoralis was characterized by relatively high net primary production rates (up to $13 \mathrm{mgO}_{2} \mathrm{gDW}^{-1} \mathrm{~h}^{-1}$ ) obtained at $0.5 \mathrm{~m}$ depth. In comparison with the perennial algal species Fucus vesiculosus and Furcellaria lumbricalis, P. littoralis had markedly higher (2-5 times on average) net primary production rates. No great differences were found between the maximum net production rates measured for $P$. littoralis and the green alga Enteromorpha intestinalis. At the same time markedly higher net primary production rates (peak values reaching $26 \mathrm{mgO}_{2} \mathrm{gDW}^{-1} \mathrm{~h}^{-1}$ ) compared to $P$. littoralis were measured for the opportunistic green algal species Cladophora glomerata.
\end{abstract}

Key words: net primary production rate, Pilayella littoralis, Cladophora glomerata, Enteromorpha intestinalis, Fucus vesiculosus, Furcellaria lumbricalis, Kõiguste Bay.

\section{INTRODUCTION}

Changes in the coastal phytobenthos communities have been documented in different parts of the Baltic Sea during the last decades (e.g. Hällfors et al., 1984; Plinski \& Florczyk, 1984; Kautsky et al., 1986; Trei et al., 1987; Vogt \&

*Corresponding author, tiina@klab.envir.ee 
Schramm, 1991; Kukk, 1997). With the decline of the perennial (first of all Fucus vesiculosus) vegetation a simultaneous increase in filamentous algae has been reported from several parts of the Baltic Sea (Kangas et al., 1982; Haahtela, 1984; Mäkinen et al., 1984; Kukk, 1985; Rönnberg et al., 1985; Kautsky et al., 1986, 1992; Breuer \& Schramm, 1988; Baden et al., 1990; Kukk \& Martin, 1992; Kiirikki \& Lehvo, 1997). The enhanced nutrient contents in the water and decreased water transparency have been considered to favour extensive growth of ephemeral filamentous, predominantly green algal species such as Cladophora glomerata and Enteromorpha sp. (e.g. Wallentinus, 1978; Kautsky et al., 1986; Baden et al., 1990). However, besides the macroalgal blooms dominated by the above-mentioned green algal species, mass occurrence of the brown alga Pilayella littoralis is nowadays an increasingly more frequent phenomenon documented by several authors (e.g. Vogt \& Schramm, 1991; Kiirikki \& Lehvo, 1997; Lotze, 1998) in the northern as well in the southern Baltic Sea.

In Kõiguste Bay, northeastern Baltic Sea, notable expansion of P. littoralis was observed in 1995-98. Up to 1995 the perennial algal species Fucus vesiculosus and Furcellaria lumbricalis dominated in the benthic vegetation of Kõiguste Bay, but already in 1998 P. littoralis was dominant down to $8 \mathrm{~m}$ depth. The species occurred as epilithic or epiphytic (mainly on F. vesiculosus) at smaller depths and was freefloating at greater depths (Kotta et al., 2000).

In 1997-2001, within the framework of different projects, several in situ net primary production measurement series were carried out with different macroalgal species common in the benthic vegetation of Kõiguste Bay. This paper focuses mainly on the comparison of net primary production rates measured for the dominating algal species in the area ( $P$. littoralis) and co-occurring species (incl. ephemeral green algae $C$. glomerata and E. intestinalis and perennial $F$. lumbricalis and $F$. vesiculosus).

\section{MATERIAL AND METHODS}

The in situ net primary production (NP) measurements were carried out in Kõiguste Bay, northeastern Baltic Sea (Fig. 1). Kõiguste Bay belongs among the least eutrophied areas of the Estonian coastal sea (Suursaar, 1995).

The algal material - Pilayella littoralis (L.) Kjellm. and Fucus vesiculosus L. (Phaeophyceae); Cladophora glomerata (L.) Kütz. and Enteromorpha intestinalis (L.) Nees. (Chlorophyceae); Furcellaria lumbricalis (Huds.) J. V. Lamour. (Rhodophyceae) - was collected at depths from 0.5 to $4 \mathrm{~m}$. The net primary production (i.e. net photosynthetic) rates were measured using the oxygen method. Samples of algal material of about $0.05 \mathrm{~g}$ (dry weight) were incubated in $600 \mathrm{~mL}$ glass bottles (the bottles were large enough to guarantee that depletion of 


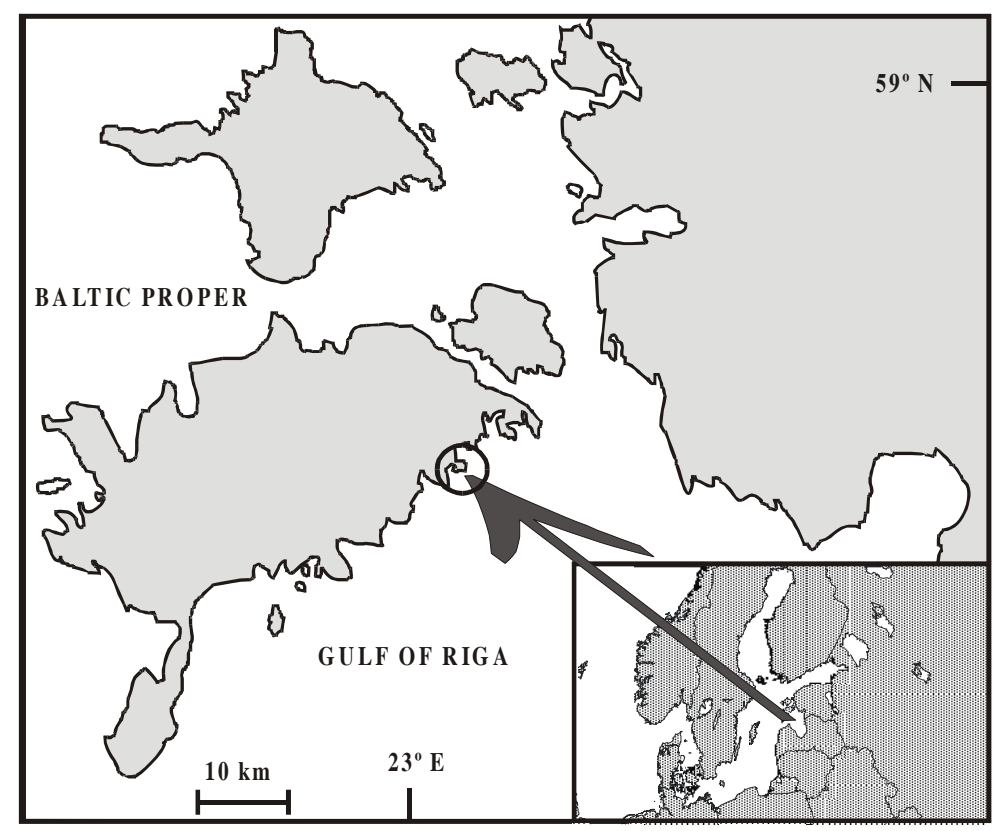

Fig. 1. Study area. The circle shows the location of Kõiguste Bay.

nutrients or carbon did not affect the photosynthetic performance of test algae) filled with seawater. The samples were incubated horizontally on special trays at a depth of $0.5 \mathrm{~m}$. Bottles without algae served as controls.

The changes in the dissolved oxygen concentration were measured by an oxygen meter OXI 92 (Kotta et al., 2000). At the time of the incubation the total insolation above the water surface was measured with a pyranometer. The obtained values were converted to $\mu \mathrm{mol} \mathrm{m}^{-2} \mathrm{~s}^{-1}$ (Lüning, 1981) and transformed to PAR (photosynthetically active radiation) by multiplying with a factor of 0.45 (Bröckel, 1975).

\section{RESULTS}

Generally the maximum NP rates of P. littoralis varied between 5 and $7 \mathrm{mgO}_{2} \mathrm{gDW}^{-1} \mathrm{~h}^{-1}$, resulting in daily $\mathrm{NP}$ rates (i.e. measured over a 24 hour period) up to $66 \mathrm{mgO}_{2} \mathrm{gDW}^{-1} 24 \mathrm{~h}^{-1}$. As a rule NP rates peaked already in April despite the relatively low water temperature i.e. below $12^{\circ} \mathrm{C}$ (Figs. 2 and 3a). Somewhat lower NP rates were obtained for P. littoralis in May (Fig. 3a). Exceptionally high NP rates for P. littoralis - up to $13 \mathrm{mgO}_{2} \mathrm{gDW}^{-1} \mathrm{~h}^{-1}$ $\left(112 \mathrm{mgO}_{2} \mathrm{gDW}^{-1} 24 \mathrm{~h}^{-1}\right.$ ) - were measured in July 2001 (Fig. 4). 


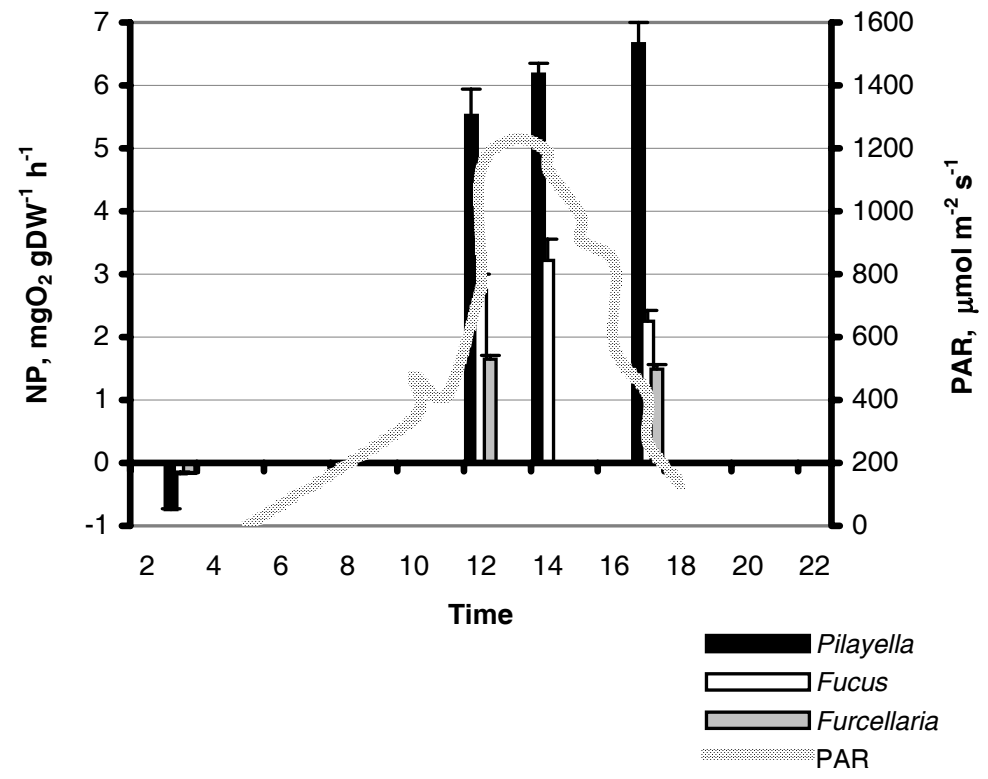

Fig. 2. Diurnal changes of net production (NP) rates $( \pm$ standard error; $n=3)$ in P. littoralis, $F$. vesiculosus, and $F$. lumbricalis plotted against surface PAR readings measured in April at water temperature of $7-12{ }^{\circ} \mathrm{C}$.

In comparison with the perennial algal species $F$. vesiculosus and F. lumbricalis, P. littoralis was responsible for markedly higher NP. The greatest differences (on average 3-5 fold) in NP rates were found between $P$. littoralis and F. lumbricalis during the diurnal incubations performed in April and July. In spring the NP rates of $F$. vesiculosus made up about $50 \%$ (Fig. 2) and in summer about $60 \%$ of the values measured for P. littoralis (Figs. 2 and 5). Much higher NP rates (peak values up to $26 \mathrm{mgO}_{2} \mathrm{gDW}^{-1} \mathrm{~h}^{-1}$, i.e. daily $\mathrm{NP}$ of $237 \mathrm{mgO}_{2} \mathrm{gDW}^{-1} 24 \mathrm{~h}^{-1}$ ) compared to P. littoralis were measured for the opportunistic green algal species $C$. glomerata. The greatest differences in the NP rates between these species were found in July-August (Figs. 3b and 6).

At the same time no great differences were found between the maximum NP rates measured for $P$. littoralis and the green alga E. intestinalis (11 and $13 \mathrm{mgO}_{2} \mathrm{gDW}^{-1} \mathrm{~h}^{-1}$, respectively). However, contrary to P. littoralis, the NP rates of E. intestinalis peaked only in August, resulting in daily NP rates as high as $73.8 \mathrm{mgO}_{2} \mathrm{gDW}^{-1} 24 \mathrm{~h}^{-1}$ (Figs. 4 and 6). 
(a)

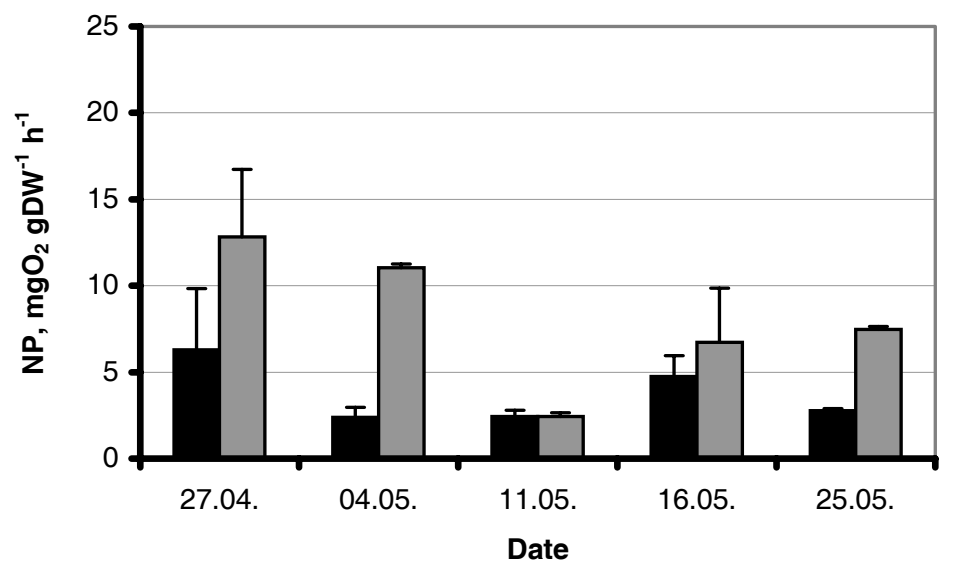

(b)

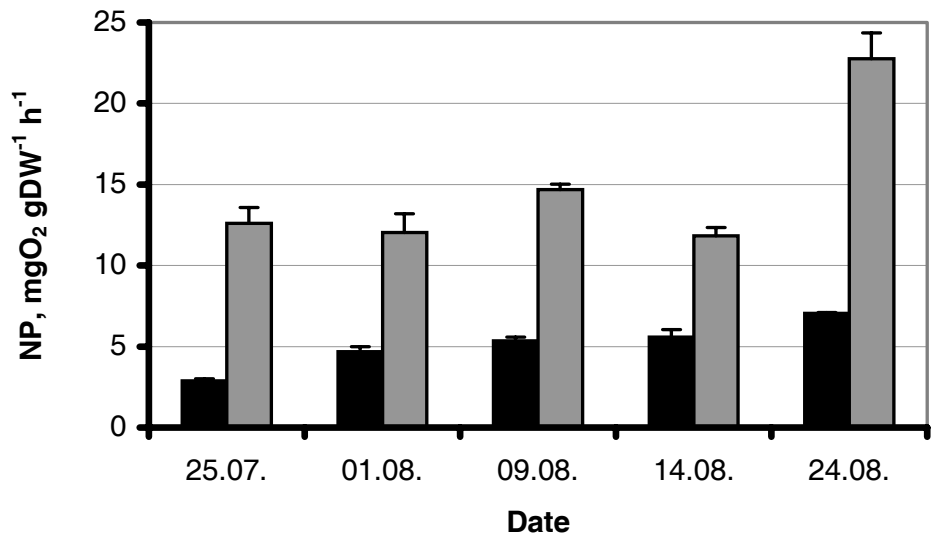

Pilayella

口Cladophora

Fig. 3. Changes in maximum net production (NP) rates ( \pm standard error; $n=3)$ measured for P. littoralis and C. glomerata: (a) in spring (April-May) at water temperature of $11-16^{\circ} \mathrm{C}$ and (b) summer (July-August) at water temperature of $17-22^{\circ} \mathrm{C}$. 


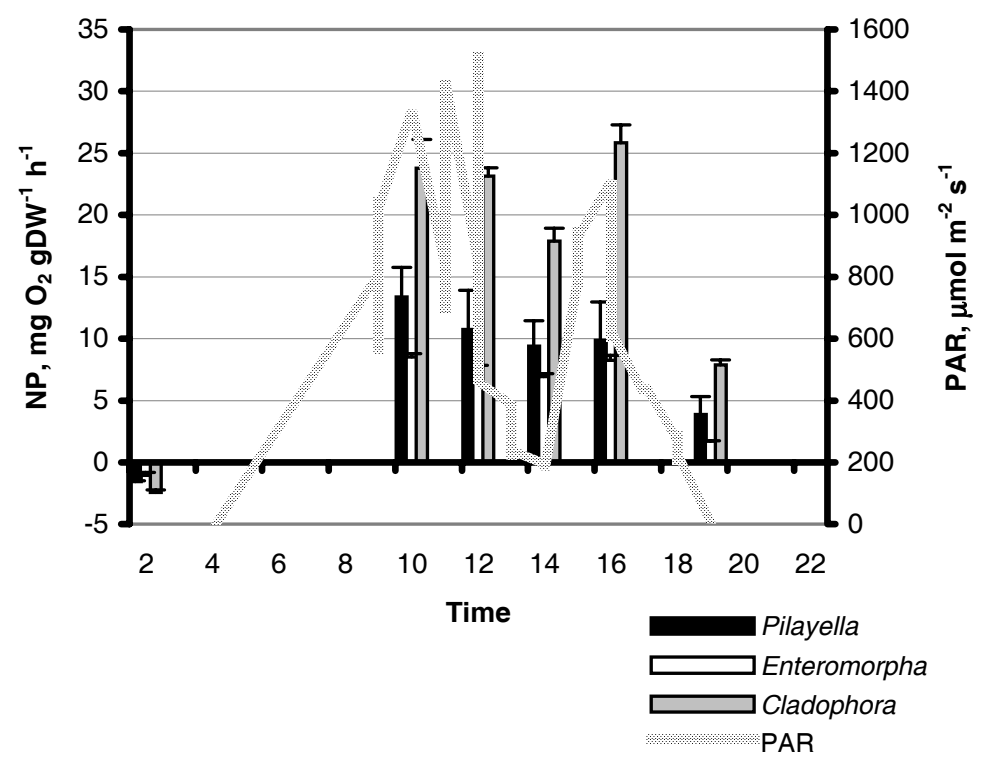

Fig. 4. Diurnal changes of net production (NP) rates $( \pm$ standard error; $n=3)$ in P. littoralis, E. intestinalis, and C. glomerata plotted against surface PAR readings measured in July 2001 at water temperature of $23-24^{\circ} \mathrm{C}$.

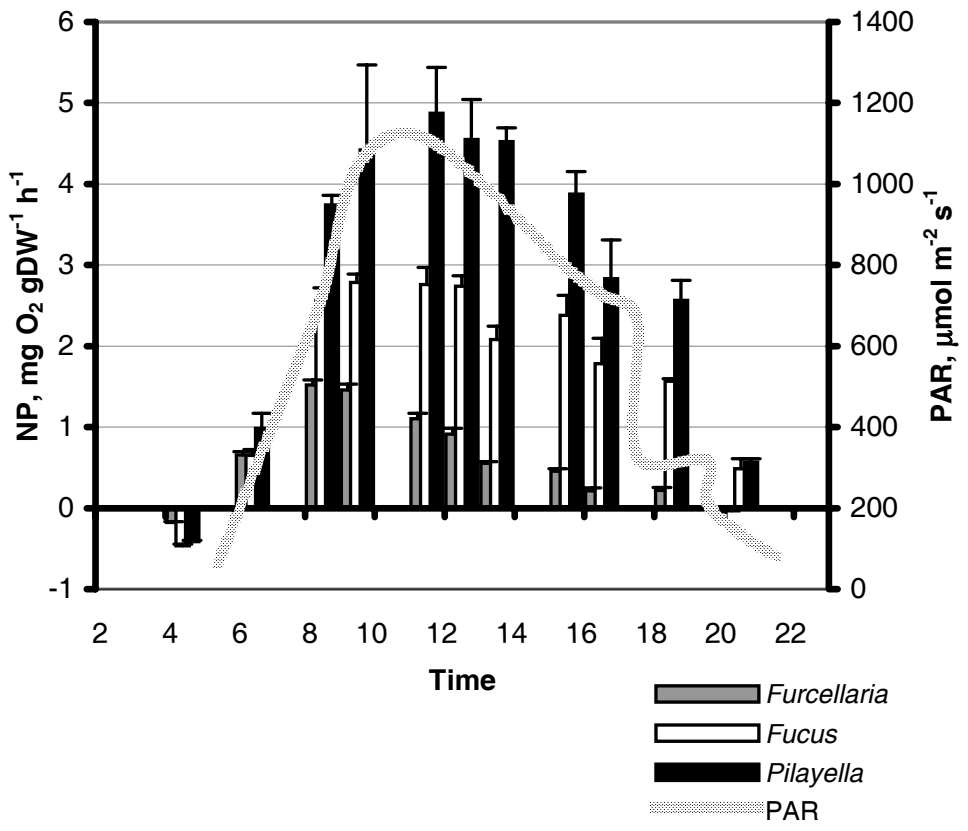

Fig. 5. Diurnal changes of net production (NP) rates ( \pm standard error; $n=3$ ) in P. littoralis, $F$. vesiculosus, and $F$. lumbricalis plotted against surface PAR readings measured in July at water temperature of $18-22^{\circ} \mathrm{C}$. 


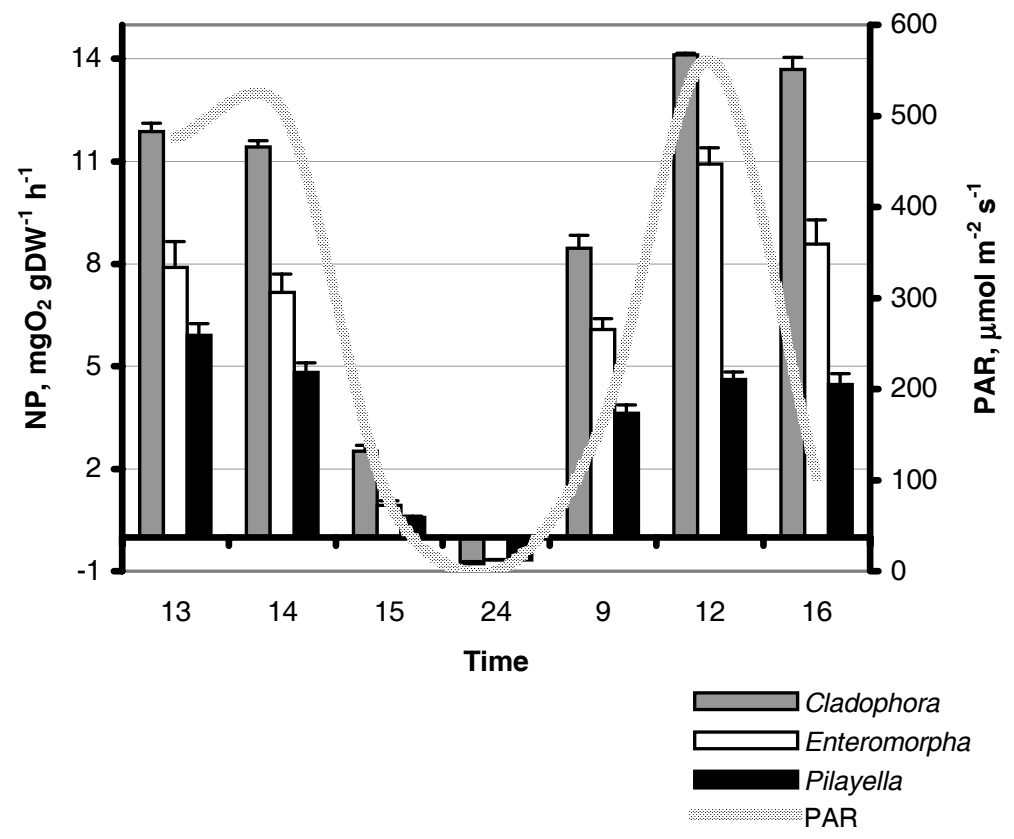

Fig. 6. Diurnal changes of net production (NP) rates $( \pm$ standard error; $n=3)$ in P. littoralis, E. intestinalis, and C. glomerata plotted against surface PAR readings measured in August at water temperature of $17-22^{\circ} \mathrm{C}$.

\section{DISCUSSION}

The in situ NP rates measured for P. littoralis at $0.5 \mathrm{~m}$ depth in Kõiguste Bay may be considered relatively high when compared with perennial algal species such as $F$. vesiculosus and $F$. lumbricalis. However, in comparison with the green alga $C$. glomerata, at least at shallow depths $(0.5 \mathrm{~m})$, P. littoralis showed notably lower primary production during our experiments.

Differences in the NP between $P$. littoralis and the above-mentioned perennial algal species are most likely determined by the morpho-physiological differences of algal thallus resulting in different growth strategy (Arnold \& Murray, 1980; Littler, 1980; Littler \& Littler, 1980). Still, attention should be paid also to the fact that naturally $F$. vesiculosus and $F$. lumbricalis inhabit shaded or deeper places being well adapted for growth at low light intensities. High PAR, exceeding at the $0.5 \mathrm{~m}$ depth several times the presumed light saturation levels for the above-mentioned species, will probably cause some decline of NP rates due to photoinhibition.

According to the functional-form model both P. littoralis and C. glomerata are regarded as opportunistic and belonging to the filamentous category (Littler \& Littler, 1980). Thus the differences in their photosynthetic capacity cannot be 
explained by different morphology alone. The colonization of P. littoralis has recently been very intensive near the surface in very early spring straight after ice break-up (Kiirikki \& Lehvo, 1997). At that time solar irradiation is still at a low level. Unfortunately, we have no data on NP rates from higher depths where similar low irradiation rates prevail, but in the Seili area, SW Finland, remarkably high NP rates have been reported at the depth of $4 \mathrm{~m}$ already at the beginning of March at the water temperature below $1{ }^{\circ} \mathrm{C}$ (Paalme \& Mäkinen, 1997). This indicates that contrary to $C$. glomerata $P$. littoralis may have been favoured by low solar irradiance and low water temperature during the recent early spring seasons.

At the beginning of our spring experiments in April the water temperature exceeded $10^{\circ} \mathrm{C}$. This together with favourable light conditions may explain the high NP rates of $C$. glomerata. Relatively low NP rates measured for $P$. littoralis in May are most likely due to changes in the physiological state of the alga accompanied with the ageing of algal thallus (incl. degeneration and detachment of filaments).

\section{ACKNOWLEDGEMENTS}

The study was carried out in the framework of the Estonian Governmental Programme No. 0200792s98 and grant No. 3825 of the Estonian Science Foundation.

\section{REFERENCES}

Arnold, K. E. \& Murray, S. N. 1980. Relationships between irradiance and photosynthesis for marine benthic green algae (Chlorophyta) of differing morphologies. J. Exp. Mar. Biol. Ecol., 43, 183-192.

Baden, S. P., Loo, L.-O., Pihl, L. \& Rosenberg, R. 1990. Effects of eutrophication on benthic communities including fish: Swedish west coast. Ambio, 19, 113-122.

Breuer, G. \& Schramm, W. 1988. Changes in macroalgal vegetation of Kiel Bight (western Baltic Sea) during the past 20 years. Kiel. Meeresforsch., 6, 241-255.

Bröckel, von K. 1975. Der Einfluss im pelagischen Ökosystem vor Boknis Eck (westl. Ostsee). Rep. SBF 95 Univ. Kiel, 10.

Haahtela, I. 1984. A hypothesis of the decline of the bladder wrack (Fucus vesiculosus L.) in SW Finland. Rep. Dept. Biol. Univ. Turku, 2, 18-21.

Hällfors, G., Kangas, P. \& Niemi, A. 1984. Recent changes in the phytal at the south coast of Finland. Ophelia Suppl., 3, 231-258.

Kangas, P., Autio, H., Hällfors, G., Luther, H., Niemi, A. \& Salemaa, A. 1982. A general model of the decline of Fucus vesiculosus at Tvärminne, south coast of Finland in 1977-81. Acta Bot. Fenn., 118, 1-27.

Kautsky, N., Kautsky, H., Kautsky, U. \& Waern, M. 1986. Decreased depth penetration of Fucus vesiculosus (L.) since the 1940's indicates eutrophication of the Baltic Sea. Mar. Ecol. Prog. Ser., 28, 1-8.

Kautsky, H., Kautsky, L., Kautsky, N. \& Lindblad, C. 1992. Studies on the Fucus vesiculosus community in the Baltic Sea. Acta Phytogeogr. Suec., 78, 33-48.

Kiirikki, M. \& Lehvo, A.-M. 1997. Life strategies of filamentous algae in the northern Baltic Proper. Sarsia, 82, 259-267. 
Kotta, J., Paalme, T., Martin, G. \& Mäkinen, A. 2000. Major changes in macroalgae community composition affect the food and habitat preference of Idotea baltica. Int. Rev. Hydrobiol., 85, 697-705.

Kukk, H. 1985. The influence of anthropogenous factors on the composition and distribution of bottom vegetation in the Gulf of Finland. Hydrobiol. Res. (Tallinn), 15, 123-126.

Kukk, H. 1997. Bottom vegetation in the coastal waters of islands in the Gulf of Finland. In Proceedings of the 14th Baltic Marine Biologists Symposium, Pärnu, Estonia, 5-8 August 1995 (Ojaveer, E., ed.), pp. 113-120. Estonian Acad. Publ., Tallinn.

Kukk, H. \& Martin, G. 1992. Long-term dynamics of the phytobenthos in Pärnu Bay, the Baltic Sea. Proc. Estonian Acad. Sci. Ecol., 2, 110-118.

Littler, M. M. 1980. Morphological form and photosynthetic performances of marine macroalgae: tests of a functional/form hypothesis. Bot. Mar., 22, 161-165.

Littler, M. M. \& Littler, D. S. 1980. The evolution of thallus form and survival strategies in benthic marine macroalgae: field and laboratory tests of a functional form model. Am. Nat., 116, 25-45.

Lotze, H. K. 1998. Population dynamics and species interactions in macroalgal blooms: abiotic versus biotic control at different life-cycle stages. Ber. Inst. Meeresk. Christian-AlbrechtsUniv. Kiel, 303.

Lüning, K. 1981. Light. In The Biology of Seaweeds (Lobban, C. S. \& Wynne, M. J., eds.), pp. 326355. Blackwell Sci. Publ., Oxford.

Mäkinen, A., Haahtela, I., Ilvessalo, H., Lehto, J. \& Rönnberg, O. 1984. Changes in the littoral rocky shore vegetation in the Seili area, SW Archipelago of Finland. Ophelia Suppl., 3, 157-166.

Paalme, T. \& Mäkinen, A. 1997. Variation in primary productivity of different Baltic macroalgal species in different seasons. NorFa project report, 9630.002-M. Nordisk Forskerutdanningsakademi, Oslo.

Plinski, M. \& Florczyk, I. 1984. Changes in the phytobenthos resulting from the eutrophication of the Puck Bay. Limnologica (Berlin), 2, 325-327.

Rönnberg, O., Lehto, J. \& Haahtela, I. 1985. Recent changes in the occurrence of Fucus vesiculosus in the Archipelago Sea, SW Finland. Ann. Bot. Fenn., 22, 231-244.

Trei, T., Kukk, H. \& Kukk, E. 1987. Phytobenthos as an indicator of the degree of pollution in the Gulf of Finland and neighbouring sea areas. Meri (Helsinki), 13, 63-110.

Suursaar, Ü. 1995. Nutrients in the Gulf of Riga. In Ecosystem of the Gulf of Riga between 1920 and 1990 (Ojaveer, E., ed.), pp. 41-50. Academia, 5.

Vogt, H. \& Schramm, W. 1991. Conspicuous decline of Fucus in Kiel Bay (Western Baltic): what are the causes? Mar. Ecol. Prog. Ser., 69, 189-194.

Wallentinus, I. 1978. Productivity studies on Baltic macroalgae. Bot. Mar., 21, 365-380.

\title{
Pilayella littoralis'e ja teiste Kõiguste lahes domineerivate makrovetikate primaarproduktsiooni võrdlus
}

\author{
Tiina Paalme ja Henn Kukk
}

Kõiguste lahe vetikakoosluses domineerivat pruunvetikat Pilayella littoralis iseloomustavad suhteliselt kõrged neto-primaarproduktsiooni (NP) väärtused. 0,5 m sügavusel oli $P$. littoralis'e NP tunduvalt kõrgem (keskmiselt 2-5 korda) kui mitmeaastastel vetikaliikidel Fucus vesiculosus ja Furcellaria lumbricalis. Samal ajal kui liikide P. littoralis ja Enteromorpha intestinalis NP väärtustes ei täheldatud olulisi erinevusi, oli Cladophora glomerata NP märkimisväärselt kõrgem. 